\title{
Daniel Grojnowski, J-K-Huysmans et la nouvelle, «Revue d'Histoire littéraire de la France» $n^{\circ} 4$
}

\section{Ida Merello}

\section{(2) OpenEdition}

1 Journals

\section{Edizione digitale}

URL: http://journals.openedition.org/studifrancesi/7674

DOI: $10.4000 /$ studifrancesi. 7674

ISSN: 2421-5856

\section{Editore}

Rosenberg \& Sellier

\section{Edizione cartacea}

Data di pubblicazione: 1 décembre 2009

Paginazione: 657

ISSN: 0039-2944

\section{Notizia bibliografica digitale}

Ida Merello, «Daniel Grojnowski, J-K-Huysmans et la nouvelle, «Revue d'Histoire littéraire de la France» n4», Studi Francesi [Online], 159 (LIII | III) | 2009, online dal 30 novembre 2015, consultato il 09 janvier 2021. URL: http://journals.openedition.org/studifrancesi/7674 ; DOI: https://doi.org/10.4000/

studifrancesi.7674

Questo documento è stato generato automaticamente il 9 janvier 2021.

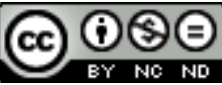

Studi Francesi è distribuita con Licenza Creative Commons Attribuzione - Non commerciale - Non opere derivate 4.0 Internazionale. 


\title{
Daniel Grojnowski, J-K-Huysmans et la nouvelle, «Revue d'Histoire littéraire de la France» ${ }^{\circ} 4$
}

\author{
Ida Merello
}

\section{NOTIZIA}

DANIEL GROJNOWSKI, J-K-Huysmans et la nouvelle, «Revue d'Histoire littéraire de la France» $n^{\circ} 4,108$ e année, déc. 2008, pp. 849-862.

1 L'A. mostra l'aporia di un Huysmans autore di novelle, collaboratore alle Soirées de Médan, eppure pressoché misconosciuto come novellista: ascrive al fiasco di La Retraite de Monsieur Bougran, che pure gli era stata commissionata da "The Universal Review" di Londra, la decisione di non cimentarsi più col genere, anche se alla fine della sua carriera raggrupperà l'insieme delle novelle per un'edizione completa delle sue opere. L'A. mette a confronto la produzione novellistica huysmansiana, a partire dai quattro testi concessi a "Le Gaulois", modellati come un reportage naturalista, sia con la sua concezione della novella, di cui mostra innanzitutto l'esitazione stessa della definizione, sia con le letture preferite dei personaggi dei suoi romanzi, attinenti soprattutto al fantastico e al macabro, in evidente contrasto con l'effettiva produzione personale, più triviale e realistica. Secondo l'A. Huysmans ha rinunciato alla novella proprio perché la sua concezione buffonesca era sconcertante e soprattutto aveva bisogno di maggiore libertà di manovra. 